\title{
Respiratory Adaptation of Anaerobically Grown Saccharomyces uvarum: Changes in Distribution of Enzymes
}

\author{
By RICHARD O. JENKINS, ' TREVOR G. CARTLEDGE, I* AND \\ DAVID LLOYD² \\ 'Department of Life Sciences, Trent Polytechnic, Nottingham NGI 4BU. UK \\ ${ }^{2}$ Department of Microbiology. University College, Newport Road, Cardiff CFI 3NR, UK
}

(Received 10 May 1984)

\begin{abstract}
Subcellular fractionations using metrizamide density gradients revealed intermediary stages of respiratory adaptation of Saccharomyces uvarum grown anaerobically in the presence of the density label 16-bromo-9-hexadecenoic acid. Prior to adaptation, activities of malate dehydrogenase and oligomycin-sensitive ATPase were contained within a membrane population at $\rho=$ $1.20 \mathrm{~g} \mathrm{ml}^{-1}$. After $10 \mathrm{~min}$ adaptation cytochrome $c$ oxidase activity was associated with these membranes, with ATPase-containing membranes at lower densities $\left(\rho=1.05\right.$ to $\left.1.14 \mathrm{~g} \mathrm{~m}^{-1}\right)$ and with membranes containing malate dehydrogenase at higher density $\left(\rho=1.24 \mathrm{~g} \mathrm{ml}^{-1}\right)$. After further adaptation these enzymes were associated firstly with two distinct membrane populations at $\rho=1.17$ and $1.20 \mathrm{~g} \mathrm{ml}^{-1}$ and finally with a single population of mitochondria at $\rho=1.16 \mathrm{~g} \mathrm{ml}^{-1}$. The significance of these changes is discussed in terms of mitochondrial differentiation. Peroxisomes were evident even in early stages of respiratory adaptation and were well separated from mitochondria in later stages.
\end{abstract}

\section{INTRODUCTION}

Anaerobically grown yeasts change from a fermentative to a respiratory mode of metabolism in response to aeration of the culture. The adaptation proceeds in the absence of cell multiplication (Cartledge \& Lloyd, 1973) and provides a suitable system for studying the development of respiratory apparatus. Membraneous particles containing oligomycin-sensitive ATPase ( $\mathbf{M g}^{2+}$-dependent) of anaerobically grown yeasts are thought to differentiate into fully functional mitochondria during respiratory adaptation and are termed promitochondria or mitochondrial precursors (Plattner \& Schatz, 1969; Plattner et al., 1970; Watson et al., 1970).

Cartledge \& Lloyd (1973) identified several different populations of particles after sucrose gradient fractionation of adapting cells of Saccharomyces uvarum, although the particles were not separated by equilibrium density centrifugation. The authors reported complex density changes in particles containing oligomycin-sensitive ATPase and cytochrome $c$ oxidase and proposed that assembly of fully functional mitochondria may involve fusion of membranes which do not pre-exist in anaerobically grown cells. After sucrose gradient fractionation of adapting cells of Saccharomyces cerevisiae, Somlo \& Krupa (1974) distinguished heavy and light membrane populations by differences in ATPase : respiratory enzyme ratios. Only the heavy population was found in the cells prior to adaptation and evidence of continuity between the two populations in adapting cells was presented.

This paper investigates further changes in enzyme distributions during respiratory adaptation of yeast. By taking advantage of the unsaturated fatty acid requirement for growth under anaerobic conditions (Andreasen \& Stier, 1954), we have attempted to incorporate the density label 16-bromo-9-hexadecenoic acid into membranes of $S$. utarum cells. 


\section{METHODS}

Maintenance and growth. Saccharomyces uvarum NCYC $74 \mathrm{~S}$ was maintained on potato dextrose agar slopes. The complex medium described by Cartledge \& Lloyd (1972b) was used for growth, except that 16-bromo-9hexadecenoic acid $(0.04 \%$; added as a $27 \%$, w/v, solution in ethanol) replaced Tween 80 . The $\mathrm{pH}$ of the medium was adjusted to 4.5 using $1.0 \mathrm{M}-\mathrm{HCl}$.

Starter cultures were grown to mid-exponential phase on a rotary orbital shaker (Gallenkamp) at low r.p.m., using the medium of Duell ef al. (1964). Batch cultures ( $1.5 \mathrm{l}$ ) were grown with magnetic stirring in 2-litre conical flasks at $30^{\circ} \mathrm{C}$ under an atmosphere of nitrogen. Residual traces of oxygen were removed from high-purity nitrogen (Air Products, New Malden, UK) by passage through 3.5 I of a thick suspension of yeast cells, then through 11 of Fieser's solution $(20 \%, w / v, K O H ; 15 \%, w / v$, sodium dithionite; $2 \%, w / v$, sodium anthraquinone-2-sulphonate) and finally through 11 of water. The medium was sparged ( $20 \mathrm{to} 25 \mathrm{ml}$ nitrogen $\left.\min ^{-1}\right)$ before inoculation $(>12 \mathrm{~h})$ and during growth.

Organisms were counted in an Improved Neubauer haemocytometer (Hawksley, Lancing, Sussex, UK) after suitable dilution and mixing to separate clumps. The inoculum was added to give an initial cell concentration of $2 \cdot 4$

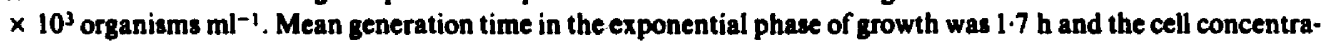
tion in the stationary phase was $9.5 \times 10^{7}$ organisms $\mathrm{ml}^{-1}$. Cultures were harvested in late exponential phase when the population was between $2 \times 10^{7}$ and $4 \times 10^{7}$ organisms $\mathrm{ml}^{-1}$.

Adaptation of cells. Adaptation at $30^{\circ} \mathrm{C}$ was in 1.51 of medium containing $(\%, w / v)$; Glucose (0.4), yeast extract (0.2), $\mathrm{CaCl}_{2}(0.033), \mathrm{KH}_{2} \mathrm{PO}_{4}(0.9), \mathrm{MgSO}_{4}(0.05)$ and $\left(\mathrm{NH}_{4}\right)_{2} \mathrm{SO}_{4}(0.6)$, at $\mathrm{pH}$ 5.0. Transfer procedures were carried out under an atmosphere of nitrogen and centrifugation was in sealed containers. The medium had been previously sparged with nitrogen for $>12 \mathrm{~h}$.

After $2 \mathrm{~h}$ of glucose derepression, equal volumes of cell suspensions were transferred to six 1 -litre conical flasks and aeration was by shaking at 300 r.p.m. on a rotary orbital shaker (Gallenkamp). Respiratory adaptation was stopped by the addition of chloramphenicol $\left(1 \mathrm{mg} \mathrm{ml}^{-1}\right)$ and cycloheximide $\left(0.1 \mathrm{mg} \mathrm{m}^{-1}\right)$.

Hervesting, preparation and disruption of spheroplasts. All centrifugation procedures were carried out at $4^{\circ} \mathrm{C}$. Cells were harvested by centrifugation for $2 \mathrm{~min}$ at $6000 \mathrm{~g}$ in a $6 \times 250 \mathrm{ml}$ rotor of an MSE 18 centrifuge.

Spheroplasts were prepared (using zymolyase) and disrupted as described previously (Jenkins et al., 1983). Whole cells and intact spheroplasts were removed by centrifugation at $1000 \mathrm{~s}$ for $5 \mathrm{~min}$. The supernatant, termed the cell extract, was carefully decanted. In experiments investigating the activities of selected enzymes at stages of respiratory adaptation, cell extracts were prepared from whole cells by ultrasonication (MSE Ultrasonicator) for three $1 \mathrm{~min}$ periods with intermittant cooling. Whole cells and intact spheroplasts were removed as described previously.

Fractionation of cell extract by zonal centrifugation. Fractionations through metrizamide gradients were carried out as described previously (Jenkins et al., 1983).

Enzyme assays. Spectrophotometric assays were carried out at $30^{\circ} \mathrm{C}$ using a Pye-Unicam SP 1800 spectrophotometer. Malate dehydrogenase (EC 1.1.1.37) was assayed as described by Kitto (1969) except that 0.1 m-potassium phosphate buffer, pH 7.8, was used. Cytochrome $c$ oxidase (EC 1.9.3.1) was assayed according to Smith (1955) except that cytochrome $c$ was previously reduced with dithionite and passed through a G2S Sephadex column. Catalase (EC 1.11.1.6) was assayed as described by Fukui et al. (1975) except that 0-02 $\mathrm{M}$-potassium phosphate buffer, pH 7.4, was used. Assay mixtures for ATPase (EC 3.6.1.3) contained $0.1 \mathrm{M}-\mathrm{Tris} / \mathrm{HCl}$, pH 9.5, $4 \mathrm{~mm}-\mathrm{MgCl}_{2}$ and $2.4 \mathrm{~mm}-\mathrm{ATP}$ (disodium salt); inorganic phosphate was measured according to Fiske \& Subbarow (1925). In assays of oligomycin-insensitive ATPase, the inhibitor:protein ratio was between 20 and $30 \mu \mathrm{g} \mathrm{mg}^{-1}$.

'Triton X-100 (final concentration $0.01 \%$ was routinely added to enzyme incubation mixtures for malate dehydrogenase and cytochrome $c$ oxidase.

Analytical methods and chemicals. Protein was measured by the Lowry method with bovine serum albumin as standard. Exclusion of metrizamide interference in protein determinations was as described previously (Jenkins et al., 1983).

16-Bromo-9-hexadecenoic acid was synthesized in our laboratory from $\alpha-9,10,16$-tribromopalmitic acid by the method of Blomquist \& Holley (1948). The method of Hunsdiecker (1943) was used to synthesize tribromopalmitic acid from aleuritic acid.

Enzyme substrates were obtained from Sigma. Aleuritic acid and hydrogen bromide/acetic acid were obtained from Fluorochem (Glowop, UK). Metrizamide was obtained from Nyegaard (Oslo, Norway) and all other chemicals were from BDH.

\section{RESULTS}

The process of respiratory adaptation was followed by measuring activities of cytochrome $c$ oxidase and catalase in cell extracts (Table 1). Cytochrome $c$ oxidase was not detectable in extracts of anaerobically grown cells even after $2 \mathrm{~h}$ of anaerobic glucose derepression, but showed 


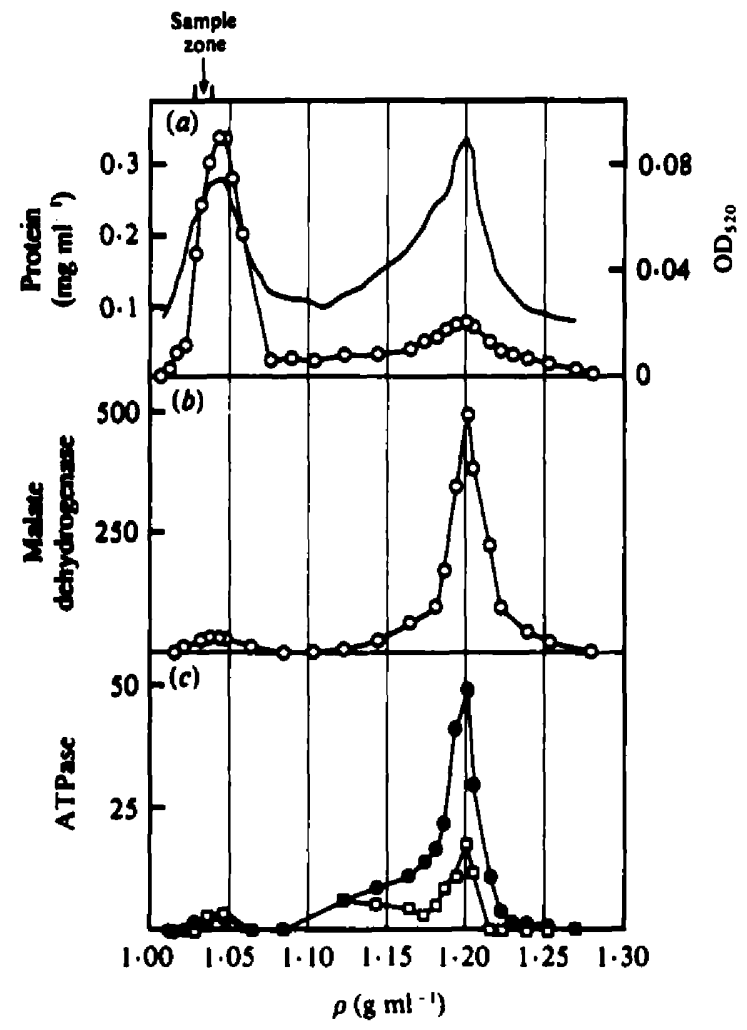

Fig. I. Zonal centrifugation of a cell extract of anaerobically grown glucose-derepressed cells. Cell extract $(10 \mathrm{ml})$ containing $186 \mathrm{mg}$ of protein was loaded on the gradient. Centrifugation was at 20000 r.p.m. for $180 \mathrm{~min}\left(6 \times 10^{6} \mathrm{~s}\right.$-min at the sample zone; $\left.\int 6 \omega^{2} \mathrm{~d} t=4.7 \times 10^{10} \mathrm{rad}^{2} \mathrm{~s}^{-1}\right)$. (a) Protein $(O)$ and $O_{320}(-)$; (b) Malate dehydrogenase (O); (c) ATPase (O) and oligomycin-insensitive

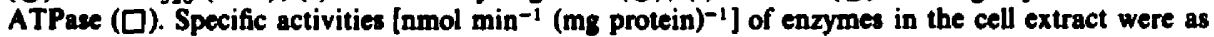
follows (recoveries in parentheses): malate dehydrogenase, 45 (142\%); ATPase, 29 (54\%). Protein recovery was $96 \%$.

Table 1. Activities of cytochrome coxidase and catalase in cell extracts during glucose derepression and respiratory adaptation of anaerobically grown $S$. uvarum

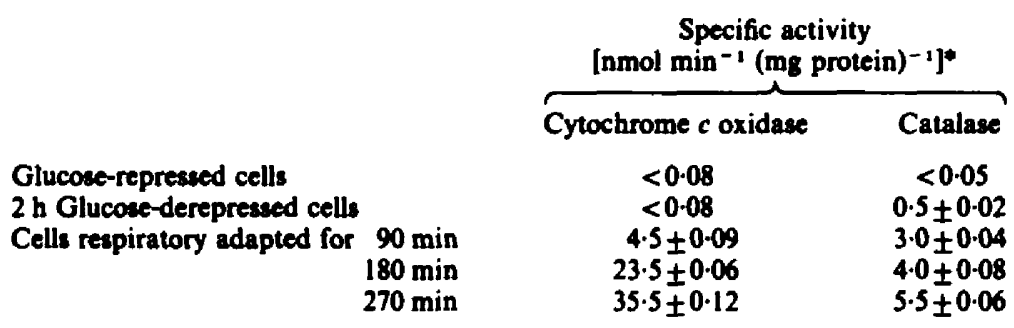

- The values presented are the means \pm SD of enzyme specific activities obtained from four experiments.

a marked increase during the period of respiratory adaptation. After aeration for $3 \mathrm{~h}$ the specific activity of cytochrome $c$ oxidase was similar to that reported by Cartledge \& Lloyd (1972a) for aerobically grown, glucose-derepressed cells. Although catalase was not detectable in extracts of anaerobically grown glucose-repressed cells, some activity was found after anaerobic glucose derepression. Catalase activity increased steadily throughout the $4.5 \mathrm{~h}$ respiratory adaptation period to more than $80 \%$ of the activity found in aerobically grown glucose-derepressed cells (Cartledge \& Lloyd, 1972a). 


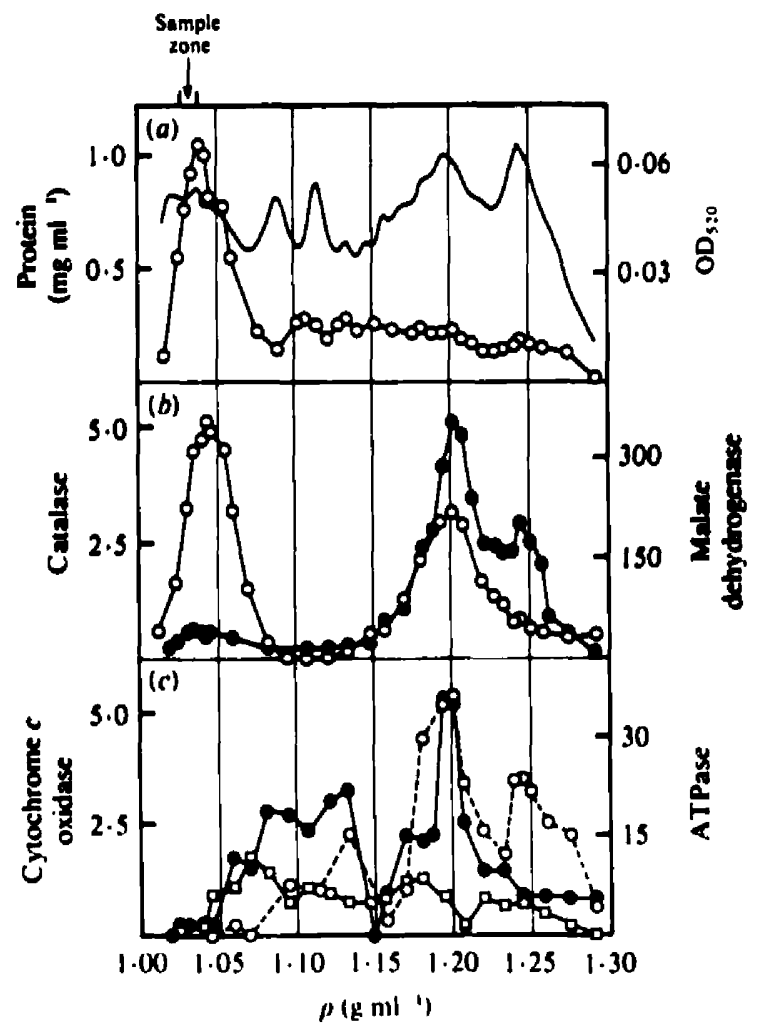

Fig. 2. Zonal centrifugation of a cell extract of $10 \mathrm{~min}$ respiratory adapted cells. Cell extract ( $10 \mathrm{ml})$ containing $134 \mathrm{mg}$ of protein was loaded on the gradient. Centrifugation was as in Fig. 1. (a) Protein $(O)$ and $O D_{520}(-) ;(b)$ catalase $(O)$ and malate dehydrogenase $(O)$; (c) cytochrome $c$ oxidase $(O)$, ATPase (O) and oligomycin-insensitive ATPase ( $\square)$. Specific activities [nmol min $^{-1}\left(\mathrm{mg}_{\mathrm{g}}\right.$ protein) ${ }^{-1}$ ] of enzymes in the cell extract were as follows (recoveries in parentheses): catalase, 5.4 (106\%); malate dehydrogenase, 204 (142\%); cytochrome c oxidase, 7.7 (78\%); ATPase, 45 (58\%). Protein recovery was $113 \%$.

There was no apparent increase in cell numbers during anaerobic glucose derepression. During respiratory adaptation for $4.5 \mathrm{~h}$ the cell count increased from $2.5 \times 10^{7}$ to $3.6 \times 10^{7}$ organisms $\mathrm{ml}^{-1}$.

\section{Fractionation of extracts of anaerobically grown cells after glucose derepression and respiratory adaptation}

After anaerobic glucose derepression, the profile of $\mathrm{OD}_{520}$ (Pye-Unicam SP 1800) of fractions eluted from the zonal rotor showed peaks in both the sample zone and at $\rho=1.20 \mathrm{~g} \mathrm{ml}^{-1}$ (Fig. $1 a$ ); the former zone contained approximately $70 \%$ of protein and the latter contained most of the remaining protein (Fig. $1 a$ ). The sedimentable zone also contained virtually all of the recovered activities of malate dehydrogenase (Fig. $1 b$ ) and oligomycin-sensitive ATPase (Fig. $1 c$ ).

After respiratory adaptation for $10 \mathrm{~min}$, the profile of $\mathrm{OD}_{520}$ was much more complex, with distinct peaks at $1.04,1.09,1 \cdot 11,1.20$ and $1.24 \mathrm{~g} \mathrm{ml}^{-1}$ (Fig. 2a). The region at $\rho=1.04 \mathrm{~g} \mathrm{ml}^{-1}$ corresponded with the sample zone and contained approximately $60 \%$ of both protein (Fig. $2 a$ ) and catalase activity (Fig. $2 b$ ). Remaining protein was distributed throughout the gradient with no distinct maximum, and sedimentable catalase activity was located in the zone at $\rho=$ $1.20 \mathrm{~g} \mathrm{ml}^{-1}$. The most active fractions of malate dehydrogenase (Fig. 2b), cytochrome $c$ oxidase (Fig. 2c) and oligomycin-sensitive ATPase (Fig. 2c) were again found at $\rho=1.20 \mathrm{~g} \mathrm{ml}^{-1}$. Further peaks of malate dehydrogenase and cytochrome $c$ oxidase, however, were located at $\rho=$ $1.24 \mathrm{~g} \mathrm{ml}^{-1}$, although little oligomycin-sensitive ATPase was recovered from this region. 


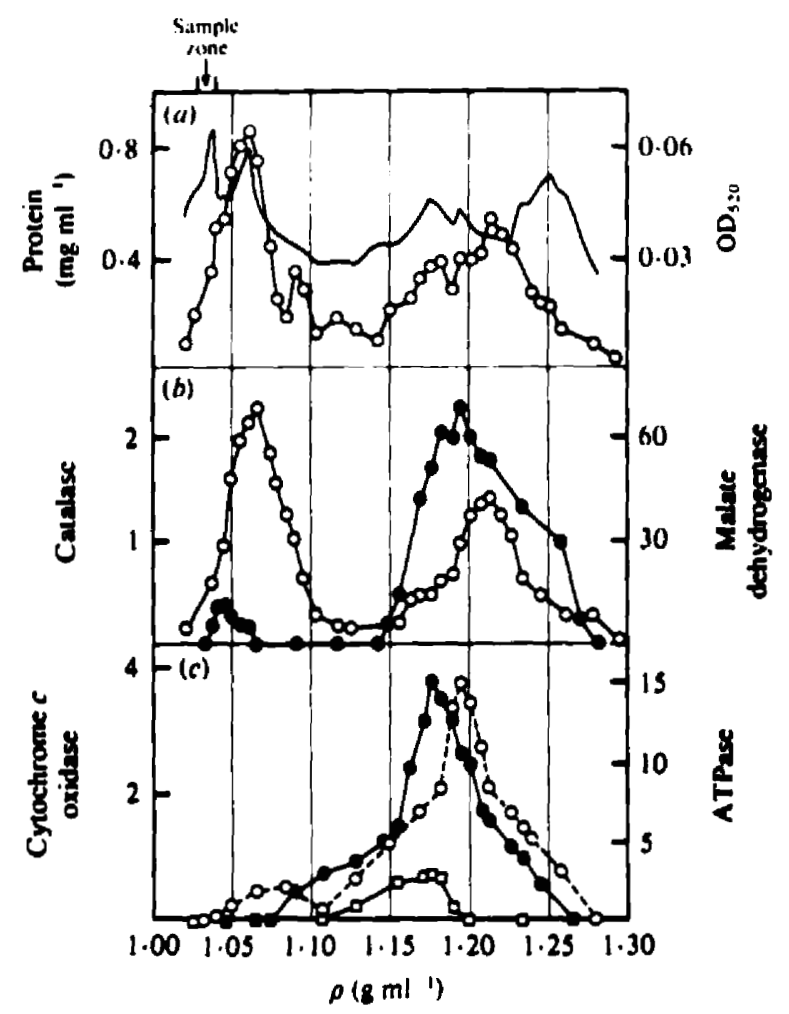

Fig. 3. Zonal centrifugation of a cell extract of $30 \mathrm{~min}$ respiratory adapted cells. Cell extract ( $10 \mathrm{ml})$ containing $76 \mathrm{mg}$ of protein was loaded on the gradient. Centrifugation was as in Fig. 1. (a) Protein (O) and $\mathrm{OD}_{520}(-) ;(b)$ catalase $(O)$ and malate dehydrogenase $(O) ;(c)$ cytochrome $c$ oxidase $(O)$, ATPase (O) and oligomycin-insensitive ATPase ( $\square)$. Specific activities [nmol $\min ^{-1}\left(\mathrm{mg}_{\mathrm{g}}\right.$ protein) ${ }^{-1}$ ] of enzymes in the cell extract were as follows (recoveries in parentheses): catalase, $4.8(96 \%)$; malate dehydrogenase, $106(108 \%)$; cytochrome c oxidase. $8.9(73 \%)$; ATPase, $47(45 \%)$. Protein recovery was $119 \%$.

Proportions of cytochrome $c$ oxidase $(20 \%)$ and oligomycin-sensitive ATPase $(45 \%)$ activities were also recovered over densities of 1.05 to $1.14 \mathrm{~g} \mathrm{ml}^{-1}$.

After respiratory adaptation for $30 \mathrm{~min}$, the profile of $\mathrm{OD}_{520}$ (Fig. $3 a$ ) again indicated at least five regions on the gradient, but at densities of $1.04,1.06,1.17,1.19$ and $1.25 \mathrm{~g} \mathrm{ml}^{-1}$. Non-sedimentable portions of protein $(48 \%$; Fig. $3 a$ ) and catalase activity $(55 \% ;$ Fig. $3 b)$ were recovered from the zone at $\rho=1.06 \mathrm{~g} \mathrm{ml}^{-1}$. Sedimentable protein showed a complex distribution, particularly over densities of 1.15 to $1.25 \mathrm{~g} \mathrm{ml}^{-1}$. Sedimentable activity of catalase was also recovered over these densities with peak activities at $\rho=1.21 \mathrm{~g} \mathrm{ml}^{-1}$. Activities of malate dehydrogenase (Fig. $3 b$ ) and cytochrome $c$ oxidase (Fig. $3 c$ ) were broadly distributed, mainly over densities of $\rho$ $=1.15$ to $1.25 \mathrm{~g} \mathrm{~m}^{-1}$, and showed corresponding peaks of activity at $\rho=1.19 \mathrm{~g} \mathrm{ml}^{-1}$. ATPase activity was also broadly distributed $\left(\rho=1.10\right.$ to $\left.1.25 \mathrm{~g} \mathrm{ml}^{-1}\right)$ but peak activity of this enzyme was located at the lower density of $\rho=1.17 \mathrm{~g} \mathrm{ml}^{-1}$.

After respiratory adaptation for $180 \mathrm{~min}$, the profile of $\mathrm{OD}_{520}$ showed only two peaks: one corresponding with the sample zone and the other at $\rho=1.16 \mathrm{~g} \mathrm{ml}^{-1}$ (Fig. $4 a$ ). The sample zone contained $55 \%$ of protein (Fig. $4 a$ ), $58 \%$ of catalase activity (Fig. $4 b$ ) and $46 \%$ of malate dehydrogenase activity (Fig. $4 b$ ). The region at $\rho=1.16 \mathrm{~g} \mathrm{ml}^{-1}$ contained most of the remaining protein, sedimentable activity of malate dehydrogenase and all the recovered activities of cytochrome $c$ oxidase and oligomycin-sensitive ATPase (Fig. 4c). Sedimentable catalase activity was recovered mainly over densities of 1.18 to $1.21 \mathrm{~g} \mathrm{ml}^{-1}$ (Fig. 4 b). 


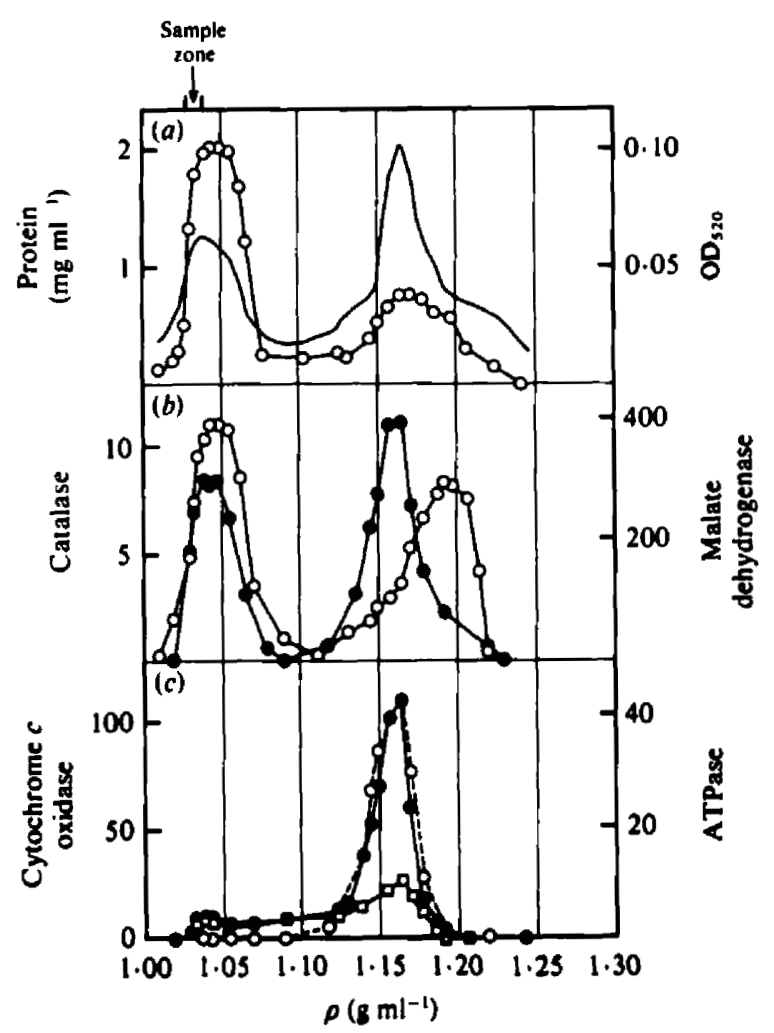

Fig. 4. Zonal centrifugation of a cell extract of $180 \mathrm{~min}$ respiratory adapted cells. Cell extract $(10 \mathrm{ml})$ containing $239 \mathrm{mg}$ of protein was loaded on the gradient. Centrifugation was as in Fig. 1. (a) Protein $(O)$ and $\mathrm{OD}_{320}(-)$; (b) catalase $(O)$ and malate dehydrogenase (O); (c) cytochrome $c$ oxidase $(O)$, ATPase (O) and oligomycin-insensitive ATPase $(\square)$. Specific activities [nmol min $^{-1}$ (mg protein) ${ }^{-1}$ ] of enzymes in the cell extract were as follows (recoveries in parentheses): catalase, $8(87 \%)$; malate dehydrogenase, $215(92 \%)$; cytochrome c oxidase, $29(87 \%)$; ATPase, 21 (57\%). Protein recovery was $106 \%$.

\section{DISCUSSION}

The growth kinetics of the culture indicate that 16-bromo-9-hexadecenoic acid serves readily as a source of unsaturated fatty acid for anaerobically grown $S$. uvarum. The density-labelled promitochondria of the glucose-repressed cells have a higher equilibrium density in sucrose ( $\rho=1.25 \mathrm{~g} \mathrm{mi}^{-1} ; \mathbf{R}$. O. Jenkins, unpublished results) than those of yeast cells supplemented during growth with Tween $80(\rho)=1.23 \mathrm{~g} \mathrm{~m}^{-1}$; Cartledge \& Lloyd, $1972 b$; Somlo \& Krupa, 1974). After anaerobic glucose derepression, respiratory adaptation proceeds rapidly and in the absence of significant net growth of culture.

Separation of organelles was best achieved by fractionation of cell extracts using metrizamide gradients as opposed to the sucrose gradients previously used (Cartledge \& Lloyd, 1973; R. O. Jenkins, unpublished results). The equilibrium density of promitochondria in metrizamide was $1.20 \mathrm{~g} \mathrm{ml}^{-1}$. After respiratory adaptation for only $10 \mathrm{~min}$, a large proportion of cytochrome $c$ oxidase was associated with these organelles. Remaining cytochrome $c$ oxidase was associated with particles containing ATPase at low density $\left(\rho=1.05\right.$ to $\left.1.14 \mathrm{~g} \mathrm{ml}^{-1}\right)$ and particles containing malate dehydrogenase at high density $\left(\rho=1.24 \mathrm{~g} \mathrm{ml}^{-1}\right)$; these populations were eventually lost or modified during further adaptation. After $30 \mathrm{~min}$ the equilibrium density of membranes containing ATPase had shifted from $\rho=1.20 \mathrm{~g} \mathrm{ml}^{-1}$ to $\rho=1.17 \mathrm{~g} \mathrm{ml}^{-1}$, though cytochrome $c$ oxidase and malate dehydrogenase remained largely at the higher density. The ratios of oligomycin-sensitive ATPase to cytochrome $c$ oxidase at these densities (2.8 and 6.7 respectively) 
indicate heterogeneity of membraneous populations. After $180 \mathrm{~min}$, ATPase and cytochrome $c$ oxidase were contained within mitochondria with an equilibrium density of $1.16 \mathrm{~g} \mathrm{ml}^{-1}$.

The conditions employed in these fractionations did not lead to extensive solubilization $(<5 \%$ ) of mitochondrial-membrane marker enzymes. The possibility that newly assembled organelles in the early stages of adaptation are more fragile cannot be discounted, but the finding that malate dehydrogenase (a mitochondrial matrix enzyme) is virtually all sedimentable and forms discrete zones suggests that particles are not produced by organelle comminution. In addition, damage to organelles would not account for the differential ratios of membrane bound enzymes obtained after fractionation of cells adapted for $30 \mathrm{~min}$.

The density shifts in ATPase carrying membrane populations reveal intermediate stages of membrane assembly and point to possible sequential stages of in vivo mitochondrial differentiation. The concept of the promitochondrion as a mitochondrial precursor supposes that this organelle acts as a framework into which newly synthesized lipid and enzyme molecules are fitted (Plattner et al., 1970). Whilst our results do not discount this hypothesis, they support the proposal of Cartledge \& Lloyd (1973) that mitochondriogenesis may involve fusion of quite large membrane units which are synthesized de novo in early stages of respiratory adaptation. After $30 \mathrm{~min}$ adaptation, the membrane populations at $\rho=1.17$ and $1.20 \mathrm{~g} \mathrm{ml}^{-1}$ may correspond to two distinct mitochondrial populations. Several alternative mechanisms responsible for observed density changes may be proposed. The shift to lower density of membranes occurring in the $3 \mathrm{~h}$ adaptation period suggests that the higher density population (even after $30 \mathrm{~min}$ ) may be a precursor of the lighter one. Alternatively, the shift to lower density may come about through fusion of particles sedimenting to $\rho=1.10 \mathrm{~g} \mathrm{ml}^{-1}$ with other higher density particles. This interpretation is compatible with the phase transition temperature changes observed by Ainsworth et al. (1972), which show that enzymes synthesized during adaptation of $S$. cerevisiae become associated with both anaerobically formed membrane and new aerobically formed membranes.

The reasonably constant sedimentable proportions of catalase obtained for the fractionations suggests that peroxisomes are present even in early stages of respiratory adaptation. These organelles show little change of diversity during adaptation and in later stages are well separated from mitochondria.

\section{REFERENCES}

Ainsworth, P. J., Tustanoff, R. \& Ball, A. J. S (1972). Membrane phase transitions as a diagnostic tool for studying mitochondriogenesis. Biochemical and Biophysical Research Communications 47, 1299 1305.

Andreasen, A. A. \& Stier, T. J. B. (1954). Anaerobic nutrition of Saccharomyces cerevisiae. II. Unsaturated fatty acid requirement for growth in a defined medium. Journal of Cellular and Comparative Physio$\log y$ 43, 271-281.

Blomquist, A. T. \& Holley, R. W. (1948). Many membered carbon rings. III. Carboxylic acid derivatives of cycloheptadecane. Journal of the American Chemical Society 701, 36-39.

Cartzedge, T. G. \& Lloyd, D. (1972a). Subcellular fractionation by differential and zonal centrifugation of aerobically grown glucose-derepressed Saccharomyces carlsbergensis. Biochemical Journal 126. 381-393.

Cartledoe, T. G. \& Lloyd, D. (1972b). Subcellular fractionation by zonal centrifugation of glucoserepressed anaerobically grown Saccharomyces carlsbergensis. Biochemical Journal 127, 693-703.

Cartledge, T. G. \& Llovd, D. (1973). Changes in enzyme activities and distributions during glucose derepression and respiratory adaptation of anaerobi- cally grown Saccharomyces carlsbergensis. Biochemical Journal 132, 609-621.

Duell, E. A., Inque, S. \& UTter, M. F. (1964). Isolation and properties of intact mitochondria from spheroplasts of yeasts. Journal of Bacteriology 38, 1762-1768.

Fiske, C. H. \& Subanrow, Y. (1925). The colorimetric determination of phosphorus. Journal of Biological Chemistry 66, 375-382.

Fukui, S., Tanaka, A., Kawamoto, S., Yasuhara, S., Teranishi, Y. \& OsUMi, M. (1975). Ultrastructure of methanol-utilizing yeast cells: appearance of microbodies in relation to high catalase activity. Journal of Bacteriology 123, 317-328.

HUNSDIECKER, H. (1943). Beitrăge zur Kenntris makro-cyclischer Ringsysteme, III. Mitteilung: die Synthese des Zibetons. Berichte der Deutschen Chemischen Gesellschaft 76B, 142-149.

Jenkins, R. O., CartLedGe, T. G. \& Lloyd, D. (1983). Subcellular fractionation of Candida stellatoidea after growth with glucose or $n$-hexadecane. Journal of General Microbiology 129, 1171-1185.

KITTO, G. B. (1969). Intra and extra-mitochondrial malate dehydrogenase from chicken and tuna heart. Methods in Enzymology 13, 106-116.

Plattner, H. \& Schatz, G. (1969). Promitochondria 
of anaerobically grown yeasts. III. Morphology. Biochemistry 8, 339-343.

Plattiner, H., Salpeter, M. M., Saltzgaber, J. Schutz, G. (1970). Promitochondria of anaerobically grown yeast, IV. Conversion into respiring mitochondria. Proceedings of the National Academy of Sciences of the United States of America 66. 12521259.

SMITH, L. (1955). Cytochromes $a, a_{1}, a_{2}$ and $a_{3}$. Methods in Enzymology 2, 736-740.
Somlo, M. \& Krupa. M. (1974). A study of the density pattern of ATPase and respiratory enzymes during mitochondrial biogenesis of Saccharomyces cerevisiae. European Journal of Biochemistry 42, 429437.

Watson, K., Haslam, J. M. Linnane, A. W. (1970). Biogenesis of mitochondria. XII. The isolation of mitochondrial structures from anaerobically grown cells. Journal of Cell Biology 46, 88-96. 